\title{
GEOGRAPHY EDUCATIONAL SYSTEM ANALYSIS FROM THE SOCIAL MANAGEMENT POSITIONS
}

DOI: http://dx.doi.org/10.18509/GBP.2018.68

UDC: $37: 91(497.2)$

\author{
Maya Vasileva \\ Kliment Naydenov \\ Sofia University "St. Kliment Ohridski", Faculty of Geology and Geography, Bulgaria
}

\begin{abstract}
Geography education as community activity evolves in line with the changing needs of human society. At current stage geography education faces different challenges and problems in its essence and scale. This implies new realities, a new educational culture and constantly changing educational environment. It is necessary to develop and validate different educational concepts, to rethink existing ideas, formulations, solutions and experience, and to generate new ones. So the main aim of current paper is to examine geography education in Bulgaria from the point of view of social management and to present its specificity as a social system. Also, it is made an attempt to generate thematic strategy of geography education in order to draw on its current dimensions and priorities.
\end{abstract}

Keywords: geography education, social management, educational strategy

Bulgarian education, respectively the geography education in our country is carried out in conditions of centralized planning and on the basis of a class-lesson system and subject training. Like any social activity it evolves in line with the changing needs of society. At current stage it is conditioned by different in its essence and scale challenges and factors: globalization and economic and political changes in society; the dynamics of knowledgebased society and a new attitude towards knowledge; the penetration of information and communication technologies in all spheres of public life; the need to coordinate and synchronize the educational systems of the EU countries to establish a "single European education policy", etc. All this implies a new reality, a new educational culture and a quite different environment for geography education. It is necessary to develop and validate other educational concepts, to rethink existing ideas, formulations, solutions and experience, and to generate new ones. In relation to the above-mentioned the purpose of this paper is:

- to study geography education in Bulgaria from the point of view of social management;

- to explore geography educational system as a social system;

- to generate its objective strategy with a view to highlight its current dimensions and priorities.

The thematic educational cognition and knowledge is derived from the relevant scientific field, in this case from geography which is the main source (but not only) of learning content. It is transformed into a subject of study and organized in the system of geography education. Like any system it is characterized by certain parameters:

- composition (elements, components, subsystems);

- structure (functional dependency, coherence and subordination);

- organization (order, composition, configuration); 
- particular environment (which influences the geography education) [3].

Geography education is a social system i.e. it is a product, and at the same time a sphere of human activity. Its range is national with a definite development over time, and by nature - it is educational.

Geography education occupies a specific place in the general system of secondary education in our country. Consequently, the most important determinant of its status is the state educational policy. It is the state policy that directs and regulates geography education through the relevant normative documents.

Like any social system the geography education is also a complex system. There are two relatively independent subsystems - at lower and upper secondary level. Each of them has specific functions, structure and behavior but they are closely interconnected. The two subsystems form the overall organization and order, the systematicity and the consistency of geographic education over time. It should therefore be designed in its entirety and not in a ,piece“.

The learning process (from 5th to 12th grade) is understood as a "flow of changing states" and takes place over time in the functioning of geography education. It can be constructed, presented and explored in two aspects:

- statically (as an ideal model that designs in time consistent motion from class to class, from one goal to another, from one learning content to another);

- real act of interaction between the two subjects in specific conditions (as an educational process with a movement from a "learning problem" to a "solved learning problem") [3].

The geography education system is not isolated. It functions in a certain cultural and educational environment - realities that are considered as factors which influence the system. Depending on the nature of their interaction they can differ in several groups:

- factors of external cultural and educational environment (state educational policy; psychological and general didactical basis of geography education; modern geography science);

- factors of internal cultural and educational environment (normative documents, information and methodological resources, human resources);

- factors of local environment (school facilities, teacher qualifications) [2].

The cultural and educational environment is constantly changing making the geography education system manageable. The ability to change over time according to the new needs of society implies that geography education is also a dynamic system. It can react to changes in environment through new decisions taken by the involved subjects. At the same time, the sustainability of the system, the preservation of its essential characteristics within the permissible limits, is emphasized [3].

One of the most important parameters of each system is its mission and its purpose which explains its creation. The mission of geography education system in secondary school is to ensure the geography education of young people as part of their general education. "Geography education is called upon to help students better understand the spatial relationships of the Earth's surface and the nature of its utilization by man. ... to act in space wisely, to see the territorial aspects of the problems ... " [6].

In the process of current functioning of geography education arise problems and contradictions between contemporary requirements of society and its state. They can be solved in two ways:

- spontaneously (insufficiently substantiated, unintentional);

- deliberately (purposefully, science-based). 
The spontaneity and consciousness reflect above all the relationship between the set goals and the results achieved by people i.e. mainly the efficiency awareness.

Social management is an activity that establishes the conditions for overcoming the elementary and aims at purposeful solving of the problems. In general, it has a targeted impact on the basic parameters and properties of the system (composition and structure, environment, functions, behavior, dynamics) in order to achieve precisely defined goals that can be distinguished in three directions:

- maintaining (preserving) the state and its optimal functioning;

- modifying (refining) its condition for the fullest realization of its capabilities;

- improvement - qualitative changes to increase its effectiveness [4].

As a complex and continually sophisticated activity of the people, social management is a unity of functions, structures and technologies [5]. Only within a certain system a person becomes a subject and object of an organization and has a definite attitude towards such properties as integrity, order and direction. The main management functions are several: decision making, planning, organizing, working with staff, providing resources, control, regulation, etc. [1], [5]. They are related to mechanisms of organizational and managerial nature and more precisely to the hierarchy of governing bodies - structures, groups, subjects with the character and horizon of their functions.

In the context of geography education system which is too complex and analyzing it from the viewpoint of social management we can point out the following aspects:

- The Ministry of Education and Science takes top-level management decisions (develops regulatory documents, designs the system at national level, provides some resources, provides independent national control).

- Regional educational inspectorates (as a lower management structure) create the conditions for the normal functioning of the system (organize the training, provide teachers, provide control and regulation, maintain the qualification of the teachers).

- School managers take decisions to ensure successful implementation of geography training in the relevant school (teachers, school facilities, management of all school activities).

- The geography teachers take specific decisions to carry out their own activities in the local environment (they plan, organize, control, regulate, manage the classroom processes; teachers conduct the actual educational process).

And consequently, some lessons can be learned from the practice:

- The complex nature of the geography education system also determines the complexity of its management.

- The existence of many hierarchically placed controllers with different horizons of decisions in different environments with divergent relationships and interaction is a problem because any incompetent and untimely taken solution creates conditions for downsizing and deviations from the goal.

- The strong demand for better training and improving of the pedagogical staff in the field of social and educational management.

- The geography teacher takes decisions at the lowest but the very important level of implementation of the real educational process so he is the person who is most responsible for the final results.

As a tool for managing the geography educational system in the secondary school, a common subject education strategy is developed [3]. What is the essence of this strategy? It is a conceptual model that has three levels each delineating a particular aspect. 
The first level reveals the essence of the strategy as an instrument for offering solutions for geography educational system and answers the following questions:

- What are the objectives, the main tasks and the expected results of the functioning of the geography educational system? This issue imposes new demands on the objectives - to be adequate to the new society needs; to be decomposed according to the organization of the overall system; to be measurable; to outline priorities.

- What are the ways to achieve goals and what characteristics do they have? The wellestablished attributes of training process are educational content, educational process and control. They are second-order parameters of the system because they are derived from the goal and must be adequate to it.

- What is the resource providence? The answer requires a new approach to classical resources (documentation, school facilities, teachers, etc.).

The second level shows the "life" of the general subject educational strategy in geography. It reveals the stages which its existence passes and also the activities related to it:

- Strategic planning - to ensure the system development under the new environment conditions in order to successfully fulfill its mission.

- Providing resources - connected with planning and the precondition for the next stage.

- "The work of the strategy" - determined not only by its quality and resource provision but also by the overall organization of its implementation (motivation, attitudes, awareness, training of all stakeholders with respect to geography education, and especially teachers).

- Monitoring and control - presented at all stages of the "life" of a strategy and has a definite purpose (providing information on achievements and problems with a view to timely regulation, i.e. stimulating and correcting, ensuring the achievement of the intended goals).

The third level is the technology for the elaboration of the common subject educational strategy and it is defined in two stages:

- Preliminary stage - where is provided the needed information on the state of geography education; for the factors of environment; the new needs and requirements and especially the problems which the strategy should solve.

- Essential stage - ensures the establishment of the strategy.

The elaboration of the general subject educational strategy as an ideal model ( a project) implies the active participation of a wide range of community specialists - from thematic science field, geography didactics, experts, teachers, etc. It is necessary to work on the basis of in-depth constructive discussions and to conduct projects with well-defined evaluation criteria. It is crucial for successful functioning of strategy to be in terms of democracy, transparency and publicity. And that's why the results of scientific research and broad opinion polls are so strongly emphasized when the strategy is constructed and for its' functioning.

In conclusion, we will point out that this study does not claim exhaustiveness. Only basic ideas are marked in the paper and they are the basis of a larger and deeper future study.

\section{REFERENCES}

[1] Армстронг, М. Основни техники на управление, Делфин Прес, Бургас, 1994

[2] Василева, М. Опит за конструиране на модел за функциониране и мениджмънт на географското образование (Дисертация), СУ „Св. Климент Охридски“, София, 2015 
[3] Гайтанджиева, Р. Стратегия на географското образование в СОУ при новите реалности, Анубис, София, 2000

[4] Димитров, Д. Обща теория на управлението, УНСС, София, 1991

[5] Марков, М. Технология и эффективность на социального управления, Москва, Прогресс, 1982

[6] Пинчмъл, Ф. Цели и значение географическото образования. - В: Новые взгляды на географическое образование, Москва, Прогресс, 1986 